There is the general course, primarily designed to give a man the broad picture of industry and its ec snomic background and to tell him something of Unilever as a whole.

The second category, the more specialized courses, are mainly devoted to teaching a particular technique such as production study, accountancy, advertising, or some technical process.

For more senior managers the opportunity may arise of going to an outside institution such as the Administrative Staff College at Henley, Nijmegen in Holland, and the advanced courses available at such places as the Harvard School of Business Administration in the United States. People are sent to all these places, sometimes to that in their own country, sometimes abroad. Then there are the courses run by universities, summer schools of business and the like, lasting three or four weeks. Industry should make a contribution, not only by ensuring that the quality of those whom it sends as students is high, but also by seconding first-class men to assist on the instructional side. If the universities are going to develop the teaching of business administration, Lord Heyworth would favour the experiment of seconding the university teacher to industry for a year or two, and so giving him an inside view of how industry works before he returns to the university to teach.

There are certain obvious advantages in possessing a corps of managers trained up in the business, professionals who at the start of their working life have made industry in general and Unilever in particular their chosen career. But there are always the dangers of inbreeding-the tendency to rest content with things as they are and to play safe, to follow precedent, to play down initiative and originality and to keep one's nose so closely to the Unilever grindstone as to let change and development in the outside world pass by unnoticed.

It may be that more interchange from one business to another at senior levels would be no bad thing. Pension rights are sometimes a difficulty, and these should not be used for fettering a man to his present job with chains of gold. In the United States, it has become the accepted pattern for a man to move upwards by switching from one business to another without suffering any stigma of disloyalty or careerism.

\section{COURSES IN HIGHER TECHNOLOGY}

$\mathrm{T}$

HE White Paper on Technical Education which was presented to Parliament in February indicated that the annual output from advanced courses at technical colleges should be increased as soon as possible from 9,500 to 15,000 and that, as industrial techniques develop, refresher courses would be essential to provide opportunities to enable industrial personnel to keep up to date. The London and Home Counties Regional Advisory Council for Higher Technological Education hopes that, by stimulating colleges to provide special courses in branches of engineering, science, chemistry, management, production and commerce, it is making a contribution to the country's need. These are described in a recent bulletin*. The purpose of the bulletin is to give publicity to special

* Bulletin of Special Courses in Higher Technology, including Management Studies and Commerce, 1956-7. Part 1: Autumn Term 1956. Pp. 82. (London: London and Home Counties Regiona Advisory Council for Higher Technological Education, 1956.) 18. $6 d$. advanced courses held in London and the surrounding counties which do not regularly appear in college calendars or prospectuses as part of a grouped course or as subjects offered for endorsement on Higher National Certificates. They are as a rule part-time (usually evening) courses; but full-time courses which are specially arranged and are not of longer than three months' duration are also included. Short courses organized by the University of London are also described in the Bulletin.

Since the issue of the first Bulletin in August 1950 many thousands of employees have attended the courses advertised. The Council forms a link between education and industry, and requests from industry for further courses on topics of interest will be gratefully received and carefully considered.

Among the courses offered are the chemistry and technology of cosmetics, analysis of power units by the use of non-dimensional plotting, microwave tech. niques and measurements, pulse techniques, restrictive practices and monopolies, rate processes in solids, aerofoil theory and supersonic dynamics, and electronies for biologists.

\section{EARTHQUAKES IN KERN COUNTY, CALIFORNIA, DURING 1952}

$\mathbf{T}$ is probable that no earthquake in history has been studied in the field by so many people as was the Arvintehachapi (magnitude 7.7) earthquake of July 21, 1952. This earthquake, one of the greatest three in Californian history, occasioned a series of aftershocks in the southern San Joaquin Valley, 220 of which, up to the end of June 1955, attained magnitude 4 or greater (Bull. 171 of the Division of Mines, Department of Natural Resources, State of California ; by 36 authors and 16 Co-operating Agencies; pp. 283; November 1955). The focus of the shock was at lat. $35^{\circ} 00^{\prime} \pm 3^{\prime} \mathrm{N}$., long. $119^{\circ} 01^{\prime} \pm$ $11^{\prime}$ W., depth about $15 \mathrm{~km}$., and it occurred at $11 \mathrm{~h}$. $52 \mathrm{~m} .14 \cdot 2 \mathrm{~s} . \pm 0 \cdot 13 \mathrm{~s}$. The epicentre was near the eastern end of Wheeler Ridge on the Whitewolf steep reverse fault. This thrust has a strike N. $50^{\circ} \mathrm{E}$. and is rather more than thirty-two miles in horizontal extent. B. Gutenberg has calculated that at the focus the fault plane has a dip of about $60^{\circ}-66^{\circ}$ towards E. $50^{\circ} \mathrm{S}$. and that the slip along the fault at this depth when the earthquake happened was roughly up towards north in the upper (south-eastern) block relative to the lower (north-western) block. The vertical component of the slip was about 1.4 times that of the horizontal, the horizontal component corresponding to a relative movement northeast in the upper block and south-west in the lower block.

Surface measurements were made by triangulation by officers of the United States Coast Guard Service. Horizontal movements were small, and the Bear Mountain block moved north-east about two feet. Some fifteen miles south of Bakersfield the differences in elevation were $3-4 \mathrm{ft}$., the area to the south being uplifted and the area to the north lowered. The sharpest break was six miles south of Arvin, at Comanche Point. According to J. P. Buwalda and Pierre St. Amand, the earthquake did not develop a simple clean-cut trace along the fault, like the strikeslip ruptures on the San Andreas fault near San Francisco in 1906 and in the Imperial Valley in 1940, 